\title{
52. Training translators in the Digital age: Students of translation and their readiness for online learning
}

\section{Nurcihan YÜRÜK1}

\begin{abstract}
APA: Yürük, N. (2021). Training translators in the Digital age: Students of translation and their readiness for online learning. RumeliDE Dil ve Edebiyat Araştırmaları Dergisi, (23), 823-840. DOI: $10.29000 /$ rumelide.949702.
\end{abstract}

\begin{abstract}
Due to Covid 19 today, most universities in Turkey have preferred online teaching methods for the courses in their programmes. Therefore, students' readiness is important in the design and implementation of online learning. Also, their satisfaction with online courses is a necessary process for online learning applications to be successful. The aim of this study is to investigate the level of online readiness of students (1st, 2nd, and 3rd students) at Translation and Interpretation Department at Selçuk University. The data was gathered through the The Scale of Online Learning Readiness (Yurdugül and Alsancak Srrakaya, 2013) including five dimensions (18 items with a 5 point Lickert scale) as computer/Internet self-efficacy, self-directed learning, and motivation for learning, learner control, and online communication self-efficacy. The reliability coefficient of the scale was found to be Cronbach's Alpha coefficient $(\alpha=.864)$. The study shows that students at all class levels are familiar with the teaching in an online environment and do not have any difficulties. Also, it was found that male students had higher Online Communication Self-Efficacy levels than female students. It was determined that those aged 24 and above were more successful in managing their own learning than those in the 18-20 age groups. There was a significant difference was found between Computer and Internet Self-Efficacy sub-factor and owning a computer and it was found that those who participated in web-based training were higher in both the total and the Computer and Internet Self-Efficacy sub-factor compared to those who did not.
\end{abstract}

Keywords: Online learning, learning readiness, translation training, distance education, Covid 19

\section{Dijital çă̆da çevirmen eğitimi: Mütercim ve Tercümanlık Bölümü öğrencileri ve çevirimiçi öğrenmede hazırbulunuşlukları}

\section{$\ddot{\mathbf{O z}}$}

Bugün Covid 19 nedeniyle, Türkiye'deki tüm üniversitelere çevrimiçi yöntemler kullanılarak dersler verilmektedir. Bu nedenle, çevrimiçi öğrenmenin tasarımında ve uygulanmasında öğrencilerin çevrimiçi hazırbulunuşlukları önemlidir ve öğrencilerin hazır bulunuşluklarının yanı sıra çevrimiçi derslerden memnuniyetleri, çevrimiçi öğrenme uygulamalarının başarılı olması için gerekli bir süreçtir. Bu çalışma, Selçuk Üniversitesi Mütercim Tercümanlık Anabilim Dalı öğrencilerinin (1., 2. ve 3. öğrenciler) çevrimiçi hazırlık düzeylerini araştırmayı amaçlamaktadır. Veriler, Yurdugül and Alsancak Sırakaya, (2013) tarafından geliştirilen bilgisayar / internet öz-yeterliği, öz-yönetimli öğrenme ve öğrenme motivasyonu, öğrenen kontrolü ve çevrimiçi iletişim öz yeterliği olarak beş boyut içeren 18 maddeden oluşan Lickert tipi Çevrimiçi Öğrenme Hazır Bulunuşluluk Ölçeği

Dr. Öğr. Üyesi, Selçuk Üniversitesi, Yabancı Diller Yüksekokulu, Mütercim ve Tercümanlık Bölümü, İngilizce Mütercim ve Tercümanlık Bölümü ABD (Konya, Türkiye), nurcihanbasibek@yahoo.com, ORCID ID: 0000-0001-8889-8107 [Araştırma makalesi, Makale kaylt tarihi: 29.03.2021-kabul tarihi: 20.06.2021; DOI: 10.29000/rumelide.949702], ETIK: Selçuk Üniversitesi Edebiyat Fakültesi Bilimsel Etik Değerlendirme Kurulu, 18.03.2021, 2021/07.

Adres | Address

RumeliDE Dil ve Edebiyat Araşttrmaları Dergisi $\quad$ RumeliDE Journal of Language and Literature Studies Osmanağa Mahallesi, Mürver Çiçeği Sokak, No:14/8 Osmanağa Mahallesi, Mürver Çiçeği Sokak, No:14/8

Kadıköy - ISTANBUL / TÜRKIYE 34714 Kadıköy - ISTANBUL / TURKEY 34714 e-posta: editor@rumelide.com

e-mail: editor@rumelide.com

tel: +90 505 7958124, +902167730616 phone: +90 505 7958124, +90 2167730616 
vasıtasıyla toplanmıştır. Ölçeğin güvenirlik katsayısı Cronbach's Alpha katsayısı $(\alpha=.864)$ olarak bulunmuştur. Çalışma, tüm sınıf seviyelerindeki öğrencilerin çevrimiçi ortamda öğretime aşina olduklarını ve herhangi bir zorluk yaşamadıklarını göstermektedir. Ayrıca erkek öğrencilerin Çevrimiçi İletişim Öz-Yeterlik düzeylerinin kız öğrencilere göre daha yüksek olduğu görülmüştür. 24 yaş ve üzeri olanların kendi öğrenmelerini yönetmede 18-20 yaş grubundakilere göre daha başarılı olduğu belirlenmiştir. Bilgisayar ve İnternet Öz-Yeterlik alt faktörü ile bilgisayar sahibi olma arasında anlamlı bir fark saptanmış ve web tabanlı eğitime katılanların hem toplamda hem de Bilgisayar ve İnternet Öz-Yeterliklerinde daha yüksek olduğu görülmüştür.

Anahtar kelimeler: Çevirimiçi öğrenme, öğrenmede hazırbulunuşluk, çevirmen eğitimi, uzaktan eğitim, Covid 19

\section{Introduction}

The deep effects and reflections of the crisis situation caused by the infectious disease Coronavirus (Covid-19) all over the world on health, economic, psychological, social life and education continue, and there is no definite data on when it will end. The Coronavirus (Covid-19) pandemic has affected education systems around the world, leading to widespread closure of schools and universities.

One of the most important targets for all countries, where the Coronavirus (Covid 19) pandemic is seen has been to ensure the continuation of education without interruption. In this process, countries are trying to use the existing distance education facilities, which are generally supported by different technological infrastructures, online platforms have been used for continuous learning. In some countries, learning contents were presented through televisions or other digital media. Due to Coronavirus (Covid-19) many countries like China, USA, ltaly, Spain, France, Korea, Turkey, and Germany reluctantly decided to interrupt their face-to-face teaching practices. In this process, in Turkey, schools were closed temporarily from March 16, 2020 until April 30, 2020. Distance education practices at primary and secondary level have been decided to be maintained through three TV channels and Education Information Network (EBA) (MOE, 2020). Due to the continuation of the effects of the pandemic, with a decision taken on April 29, 2020, it was announced that the school holiday period was extended until May 31, 2020, the education would continue with distance education, the first semester grades would be valid for the students to pass the class, and they would pass to the upper class in any condition. Due to the coronavirus (Covid 19) pandemic, education was suspended in the higher education system on March 12, 2020, and it was decided to continue with an open and distance learning system in the spring semester of the 2019-2020 academic year as of March 23, 2020 (YÖK, 202Of).

Many educational institutions all over the world have preferred using online means of distance education rather than face-to-face education. The education system has unexpectedly moved to electronic devices and online applications from the traditional classroom environment (Mnyanyi \& Mbwette, 2009). Many terms are used to define this type of education. Some of them include "online learning, open learning, web-based teaching, computer-based learning and e-learning" (Dhawan, 2020, p.2). What all these terms have in common is that they necessitate the use of a computer connected to internet offering the possibility to access learning anytime and anywhere. Online learning is introduced and accepted as the saviour of continuous education. Some of the features of online learning or e-learning such as accessibility, affordability and flexibility are the reasons to prefer elearning. Dhawan (2020) states that "online mode of learning is easily accessible and can even reach to

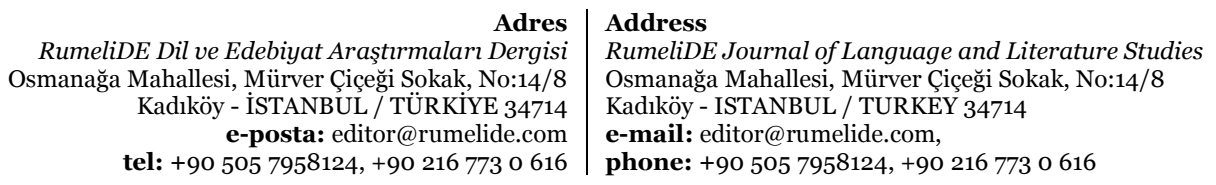


rural and remote areas", and it is also "a relatively cheaper mode of education in terms of the lower cost of transportation, accommodation, and the overall cost of institution-based learning" (p.6). He also adds that "flexibility is another interesting aspect of online learning; a learner can schedule or plan their time for completion of courses available online" (p.6).

\section{The purpose of the study}

This study aims to investigate the level of online readiness of students (1st, 2nd, and 3rd students) at Translation and Interpretation Department at Selçuk University. To look for the relationships between the students' readiness for online learning and the variables such as age, gender, class levels, webbased education experience and access to computers and Internet and finally to propose some suggestions to make online learning process more effective and beneficial for students.

\section{Literature review}

With the explosion of Covid-19, online learning gain importance globally nowadays. Today, online learning may be seen as one of the most convenient and possible ways of education under these circumstances, when the provided advantages to learners and teachers are taken into account. Therefore, in the following section, after describing e-learning, these advantages and challenges will be mentioned.

\section{Online learning}

Until 1980s, there have been some implications of distance education. With the establishment of Anadolu University Open Education Faculty, it was transformed into higher education. During 1980 os and 1990s, distance education has matured at primary, secondary and higher education levels. With the successes achieved in these years, distance education has attracted great interest and acceptance. With the developments in the field of education and information and communication technologies (ICT) from the end of the 1990's to the early 2000's, the opportunities offered by distance education have improved and it has become a part of the mainstream education in our country. In Turkey, distance education can be categorized under the heading of four periods. Bozkurt (2017) explained these periods in detail in his study. When these periods are examined, it can be seen that information network and web-based instruction were first used in 1996 by Bilkent University for the lectures from the USA through video conference system. Thenceforth, online learning or e-learning have been used in many educational settings.

Soni (2020) describes online learning "as a method of learning that is carried out through electronic media." (p. 4), and he also defines it "as virtual or e- learning, via emails, documents, presentations or webinars, providing a way to exchange reading materials using the internet." (p. 4).

Table 1. Definitions of distance learning, e-learning, and online learning

\begin{tabular}{|c|c|c|}
\hline Term & \multicolumn{2}{|l|}{ Definition } \\
\hline Distance learning & \multicolumn{2}{|c|}{$\begin{array}{l}\text { The broadest term. Encompasses both e-learning and online learning. Newby, Stepich, } \\
\text { Lehman and Russell (2000, p. 210) define distance learning as "an organized } \\
\text { instructional program in which teacher and learners are physically separated." }\end{array}$} \\
\hline E-learning & \multicolumn{2}{|c|}{$\begin{array}{l}\text { E-learning covers a wide set of applications and processes, such as Web-based learning } \\
\text { computer-based learning, virtual classrooms, and digital collaboration. It includes the } \\
\text { delivery of content via Internet, intranet/extranet (LAN/WAN), audio- and videotape, }\end{array}$} \\
\hline $\begin{array}{r}R u \\
\text { Osma }\end{array}$ & $\begin{array}{r}\text { Adres } \\
\text { il ve Edebiyat Araşturmaları Dergisi } \\
\text { allesi, Mürver Çiçeği Sokak, No:14/8 } \\
\text { dıköy - İSTANBUL / TÜRKIYE } 34714 \\
\text { e-posta: editor@rumelide.com } \\
+905057958124,+902167730616\end{array}$ & $\begin{array}{l}\text { Address } \\
\text { RumeliDE Journal of Language and Literature Studies } \\
\text { Osmanağa Mahallesi, Mürver Cicceği Sokak, No:14/8 } \\
\text { Kadıköy - ISTANBUL / TURKEY } 34714 \\
\text { e-mail: editor@ @umelide.com, } \\
\text { phone: +90 505 7958124, +90 } 216773 \text { o } 616\end{array}$ \\
\hline
\end{tabular}




\begin{tabular}{ll}
\hline & satellite broadcast, interactive TV, and CD-ROM.” Ellis and Allen (2004). \\
\hline Online learning & Volery and Lord (2000, p. 217) Used synonymously with the term online delivery, "a \\
& form of distributed learning enabled by the Internet. Online delivery goes beyond \\
traditional computer learning as it makes full use of the Internet and other digital \\
technologies. Online delivery can facilitate distance education by making course \\
material accessible anytime anywhere.
\end{tabular}

With the integration of Information and Communications Technology (ICT), e-learning becomes an important part of education. This innovative field triggers a student-centred approach and also makes learning process flexible. It is a way for learning that learners are able to access synchronous or asynchronous modes of education, audio lectures posted on open educational platforms, educational materials delivered via e-mail, virtual consultations and discussions on forums.

There has been a global shift to online methods of teaching and learning internationally due to the COVID-19 pandemic. Many institutions have been forced to adopt online pedagogy and e-learning has become more popular. As in many countries, e-learning has taken the place of traditional classrooms for the safety of the educators and learners in Turkey. Turkish universities have been using e-learning as the dominant form of teaching nowadays. Distance learning centres have been established in many Turkish, adding full online courses to their offer. It is an initiative that is mainly intended for people who want to combine education with work or other studies, who live far from academic centres, people with disabilities, and people who want to learn, but for some reason, the traditional form of learning does not suit them. However, on a larger scale, e-learning is mainly used for teaching individual subjects or as a way of individual training. For this reason, forced by the current epidemiological situation, the transition to this form of teaching in all aspects is a huge challenge for universities, institutions (in particular in terms of technology and finance), academic teachers, and students.

\section{Advantages of online learning}

Online learning meets the criteria of today's learners. For various reasons, it has thus proven to be fruitful. It can be used "at the learner's own convenience by purchasing subscriptions from different sites or logging in to access the courses at any time" (Colchester et al., 2017, p. 51). Online learning platforms enable the users to share teaching and learning sources in multiple formats, such as slideshows, audio, photographs, PDFs, e-mails, word documents, and so on.

Soni (2020) indicates that "webinars and direct communication with teachers via various chat channels or texting are the other options in e-learning processes." (p. 6). He also adds that "for such emanuals, such as PDFs, it offers free access and provides learners with direct, basic, gradual guidance to understand better." (p. 6).

During the COVID-19 crisis, e-learning proved to be beneficial in particular. During this on-going pandemic, more students have opted for online education applications. To help students learn easily from their homes, online platforms have provided free access to live lessons, and there has been a massive increase in the number students using these educational apps. These apps have features such as control over the classroom, tracking attendance, automating the time table, assigning homework and messaging.

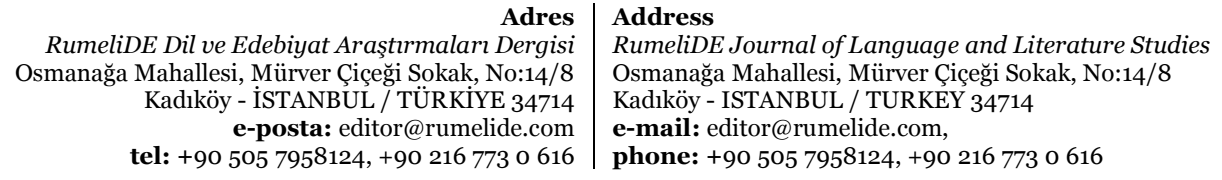

Adres
RumeliDE Dil ve Edebiyat Araşttrmaları Dergisi

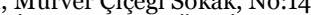
e-posta: editor@rumelide.com tel: +90 505 7958124, +90 2167730616
Address

Osmana

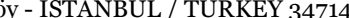

phone: +90 505 7958124, +90 2167730616 


\section{Challenges of online learning}

As a consequence of the pandemic crisis, there has been a huge, disruptive transition from the existing education system to the online education system. For the creation of successful study materials, an online course provides detailed lesson plans. Educators' lack of online teaching skills, time consuming preparation of online lesson plans, lack of sufficient technical team assistance, and traffic overload on online platforms are some of the problems of online education.

Because of their lack of a proper learning attitude, adequate learning materials, increased involvement in classroom learning, self-discipline and a learning environment in some of their homes during selfisolation, not only teachers but also students face difficulties.

There are several challenges to online learning, ranging from learning difficulties, problems for educators and problems with content. Institutions are called upon to include learners in the process of teaching and learning. Teachers have trouble "transitioning from offline to online mode, changing their teaching methodologies and methods, and managing their time", and "it is difficult to create resources that not only cover the curriculum, but also involve students" (Kebritchi et al., 2017, p.11).

The consistency of programs for e-learning is a real challenge. The government has no clear stipulation in its e-learning education policies. There is "a lack of requirements for quality management, quality control, e-resource creation and e-content delivery and this issue needs to be solved urgently so that everybody can reap the benefits of quality education through e-learning" (Cojocariu et al., 2014, p. 2002).

Affouneh et al. state that "one should not only concentrate on the pros associated with online learning during crises, but should also take into account the growth and enhancement of the standard of virtual courses provided in such emergencies" (Affouneh et al., 2020, p. 135). With e-learning, there is a lot of time and expense involved. In order to purchase and maintain equipment, train human resources and create online material, it is not as simple as it seems that a significant amount of investment is needed.

\section{Translator training and online learning}

Translational studies and the field of training translator have also been affected from the contributions of online learning to educational settings. In addition to software programs, the complementary function of computing in translational studies gave rise to some tools such as translation memory and terminology management systems. Also, corpora-related tools and machine translation have changed the job requirements for translators. Therefore, translators need to be digitally competent in those areas in order to challenge these developments. Granell (2014) explained that "due to the changeable nature of the digital era, both in terms of knowledge and technology available, these professionals must continuously develop their information competence and cope with new realities.”(p. 35). Hence, today cultural and linguistic competencies are not enough in order to be a good translator. Translation students should be equipped with digital and technological competencies, that is, digitally literate. Pym (2000, p. 3) described the integration of online learning into translator training by explaining the following advantages:

Necessary communication skills: Perhaps the most compelling reason is that professiona translating increasingly involves the use of the electronic tools used in online learning (email, attachments, websites, FTP). Since students will have to use these tools in their professional life, they might as well get used to them in their training: if the medium is not quite the whole message,

Adres Address

RumeliDE Dil ve Edebiyat Araştırmalar Dergisi $\quad$ RumeliDE Journal of Language and Literature Studies Osmanağa Mahallesi, Mürver Çiçeği Sokak, No:14/8 Osmanağa Mahallesi, Mürver Çiçeği Sokak, No:14/8 Kadıköy - İSTANBUL / TÜRKIYE 34714 Kadıköy - ISTANBUL / TURKEY 34714 e-posta: editor@rumelide.com e-mail: editor@rumelide.com tel: +90 505 7958124, +90 2167730616 phone: +90 505 7958124, +90 2167730616 
it is at least part of the competence to be acquired. The future of both translation and training would thus be to some degree pre-inscribed in the technology.

Tandem learning: Another important factor supporting online learning is the way it opens up possibilities for 'tandem' learning arrangements for students coming from different linguistic and cultural backgrounds. Therefore, they should be able to combine their complementary competencies in such a way that they effectively teach each other a lot about languages, if not about translation as such. Tandem arrangements have been extensively promoted for the learning of second languages, where they quite obviously make the most sense. Yet they appear not to have risen above the experimental level in translator training, probably because they require significant degrees of inter-institutional organization, across political and cultural boundaries.

Student demand: A third reason for online learning is that there is a strong student demand for distance courses of this kind. The demand is mainly from mature-age students, mostly professionally employed, who want to gain skills of this kind or who are interested in obtaining a recognized qualification. This is the market traditionally addressed by courses at postgraduate (Masters) level. However, the progressive shift of all tertiary education into the spheres of life-long learning means that this market may also be served at second-cycle level, if not earlier. The trend is also aided to some extent by the growth in the numbers of 'international' students, those who seek skills and cultural environments that are not available in their home countries. However, such students are also in search of first-world visas and immediate linguistic contact. For them, online learning should mostly be envisaged as a means of extending or prolonging face-to-face training programs.

The use of online learning in translation training may satisfy learners' both instructional and practical needs. Pym (2000) notes that "online learning is of particular importance in translator training because the skills involved in online learning are essential for any translation practice at the professional level" (p.1). Alshebab (2013, p. 126) compared the use of electronic tools and traditional methods in a translation course. According to the results of the study there was a significant difference in learning between the students that are taught traditional methods than those who used electronic tools in learning in terms of the scores in the post-test. Also, in another study, O'Donnell (2010) used "the integration of online learning as an on-campus provision of translator training rather than pure online translation courses" (p.268). Dorri and Khani (2018) conducted a study through an online translation discussion group in telegram during a semester and students practiced and learned translation through a distance learning course. Their study showed that students' skills in translation have been improved totally. These studies were generally about learning materials, collaborative learning, and technical and pedagogical aspects of online learning. Before implementing some online learning materials or integrating some electronic tools into learning process, it is necessary to look for to what extent these students are ready for online learning.

\section{Learner readiness for online learning}

Tang and Lim (2013) described online learning readiness under three major categories: "choices for online learning as opposed to face-to-face learning instructions; competence and confidence in using the technological tools; and ability to learn separately"(p. 199). Online learning readiness can be estimated, according to Guglielmino and Guglielmino (2003), by assessing the willingness of a person to use technical resources (Schreurs, Sammour, \& Ehlers, 2008). Hung et al.(2010) studied on McVay's research (2001) that was related to student behaviours and attitudes to determine readiness, and then added some new dimensions to the readiness concept such as computer/Internet selfefficacy, learner control, motivation for learning, online communication self-efficacy and self-directed learning. In this research, learners' online learning readiness at Translation and Interpretation Department of a state university was investigated with the dimensions that Hung et al. focused in their study.

Adres

RumeliDE Dil ve Edebiyat Araşttrmaları Dergisi Osmanağa Mahallesi, Mürver Çiçeği Sokak, No:14/8 Kadıköy - ÍSTANBUL / TÜRKIYE 34714 e-posta: editor@rumelide.com tel: +90 505 7958124, +90 2167730616
Address

RumeliDE Journal of Language and Literature Studies

Osmanağa Mahallesi, Mürver Çiçeği Sokak, No:14/8

Kadıköy - ISTANBUL / TURKEY 34714

e-mail: editor@rumelide.com,

phone: +90 $5057958124,+902167730616$ 


\section{Self-directed learning (SDL)}

Knowles (1975) defines self-directed learning as "a process in which individuals take the initiative, with or without the help of others, in diagnosing their learning needs, formulating goals, identifying human and material resources, choosing and implementing appropriate learning strategies, and evaluating learning outcomes" (p. 18).

Self-directed learning is described by Knowles as "a psychological process that learner direct themselves to get knowledge and try to find ways for their problems." (p.12). Learners that have selfdirected learning abilities usually more successful in some activities they participate like doing online materials. These learners have high level of self-management strategies to deal the problems they face with. Gilbert and Driscoll (2002) stated that SDL focuses on "goal setting and choice making strategies which are crucial to collaborative learning." (p. 61). Self-directed learners tend to search the online learning platform for resources. Teo's et al., (2010) research on self-directed learning with technology (SDLT) revealed that "students' perceptions of collaborative learning can enhance students SDL." (p. 1768). The study of Lee, Tsai, Chai and Koh (2014) showed that "student SDL processes contribute to the use of Internet communication technology for collaborative learning.” (p. 428).

\section{Motivation for learning}

Among the available research, there has been a tendency to adopt "a limited view of motivation that does not acknowledge the complexity and dynamic interplay of factors underlying and influencing motivation to learn" (Hartnett, 2016, p. 1) and she added that "designing motivating learning environments has gained popularity." (p. 1). Also, Hartnett (2016) indicated that "motivation has been viewed a relatively stable personal characteristic and studies have focused on identifying lists of traits of successful learners". (p. 1). Ryan and Deci (2000, p. 58), for example, have established that "online learners have considerable freedom to decide their own learning path, a freedom that could help learners with an intrinsic motivation." Wighting, Liu, and Rovai (2008) compared online and oncampus students and the findings of the study indicated that "online students are more intrinsically motivated than their on-campus counterparts." (p. 292). Therefore, it can be said that student motivation is considered a crucial factor for success in online learning environments.

\section{Learner control}

Lawless and Brown (1997) explained that "unlike traditional learning environments, students who have the opportunity to choose what information to access and how to order information in online learning environments." (p. 118). Also, Lin and Hsieh (2001) claimed that "online learning environments offered a more flexible and more individualized learning opportunity." (p. 381). Directing students' own learning processes is expressed as learner control (Shyu \& Brown, 1992, p. 87). According to Hung et al. (2010, p. 1083) online students who create and apply their own learning method can demonstrate a better learning performance.

\section{Computer \& Internet self-efficacy}

Self-efficacy belief is defined as an individual's judgment or confidence about whether or not a person will be able to fulfil a task given or given to him (Bandura, 1977, p.195). Computer self-efficacy, which is related to the attitude towards computer technologies, the frequency of using computers, and the success of doing business using computers, is the individual's confidence in using computers (Karsten 
\& Roth, 1998, p. 17). Internet self-efficacy can be defined as the belief and confidence of individuals in using the Internet. Students' basic knowledge and skills related to computer use and their high computer self-efficacy perception are considered as one of the determining factors in the success of online learning (Çelen, Çelik \& Seferoğlu, 2011, p. 28).

\section{Online communication self-efficacy}

The self-efficacy of communication in online learning is an important dimension to overcoming the constraints of online communication. Palloff \& Pratt, (1999) suggested that "in online settings, shy students appear to engage more than in conventional environments." (p. 3). McVay (2000) reported that "it is important to build opportunities for Web-based learning interactions and interactions between students and their instructors." (p.21). According to McVay (2000) stated that "efficient students should make the most of discussion platforms as a method to engage both fellow students and educators, which can provide opportunities for richer debate and thoughtful questions for example; asking questions is a way of going deeper into the issue, and going deeper makes the subject more comprehensible." (p. 22). McVay also added that "students can take advantage of opportunities to work with other online students in order to avoid burn-out or lack of interest while learning online, using motivation and suggestions to remain motivated." (p. 22).

\section{Research questions}

1. What is the readiness level of translation and interpretation students for online learning?

2. Is there a relationship between students' class levels and their readiness for online learning?

3. Is there a relationship between students' gender and their levels of online learning readiness?

4. Is there a relationship between students' age and their levels of online learning readiness?

5. Is there a relationship between the students' readiness for online learning and their access to computer and Internet?

6. Is there a relationship between the students' readiness for online learning and web-based education experience?

\section{Method}

\section{Subjects}

The first, second- and third-year students of students who have taken all their courses asynchronously were involved in the study. The following table shows the demographic information about the participants involved in the study.

Table 2. Demographic information of the Translation and Interpretation students participating in the study

\begin{tabular}{|c|c|c|c|}
\hline $\begin{array}{l}\text { Demographic } \\
\text { Information }\end{array}$ & Categories & $\mathbf{f}$ & $\%$ \\
\hline \multirow{2}{*}{ Grade } & 1.Grade & 47 & 39.2 \\
\hline & 2.Grade & 31 & 25.8 \\
\hline $\begin{array}{r}R \\
\text { Osm }\end{array}$ & $\begin{array}{l}\text { Adres } \\
\text { debiyat Arasstrrmaları Dergisi } \\
\text { Mürver Ciçegi Sokak, No:14/8 } \\
\text { İSTANBUL / TÜRKIYY } 34714 \\
\text {-posta: editor@rumelide.com } \\
\text { O5 7958124, +90 } 216773 \text { o } 616\end{array}$ & \multicolumn{2}{|c|}{$\begin{array}{l}\text { Address } \\
\text { RumeliDE Journal of Language and Literature Studies } \\
\text { Osmanağa Mahallesi, Mürver Ciçeği Sokak, No:14/8 } \\
\text { Kadlköy - ISTANBUL / TURKEY } 34714 \\
\text { e-mail: editor@rumelide.com, } \\
\text { phone: +90 505 7958124, +90 } 216773 \text { o } 616\end{array}$} \\
\hline
\end{tabular}




\begin{tabular}{llll} 
& 3.Grade & 42 & 35.0 \\
\hline \multirow{2}{*}{ Gender } & Male & 41 & 34.2 \\
& Female & 79 & 65.8 \\
\hline \multirow{2}{*}{ Age } & $18-20$ & 68 & 56.7 \\
& $21-23$ & 41 & 34.2 \\
& 24 and above & 11 & 9.2 \\
Type of High School & Open High School & 22 & 18.3 \\
& Anatolian High School & 65 & 54.2 \\
& College & 11 & 9.2 \\
\hline Access to computer and & Vocational High School & 22 & 18.3 \\
Internet & Yes & 106 & 88.3 \\
\hline Web-Based Education & No & 14 & 11.7 \\
Experience & Yes & 61 & 50.8 \\
\hline TOTAL & No & 59 & 49.2 \\
\hline
\end{tabular}

Table 2 presents the demographic information of the students who participated in the study. The findings showed that $47(39.2 \%) 1^{\text {st }}$ grade, $31(25.8 \%) 2^{\text {nd }}$ grade and $42(35.0 \%) 3^{\text {rd }}$ grade students participated in the study. Considering gender, there were 41 (34.2\%) males and 79 (65.8\%) females. The age of the students were grouped as $68(56.7 \%)$ in the 18-20 age group, $41(34.2 \%)$ and $11(9.2 \%)$ in the 24 age group. When look at the type of high school they graduated from; students graduated from open high school 22 (18.3\%), Anatolian high school 65 (54.2\%), college 11 (9.2\%) and vocational high school 22 (18.3\%). In addition, there are 106 that access to computer and Internet (88.3\%) and 14 (11.7\%) that do not have. 61 (50.8\%) of students stated that they participate in web-based education and $59(49.2 \%)$ of the students have not had such an experience before.

\section{Data collection}

\section{Data collection instruments}

The data were gathered through an online scale. It is made up of two parts. Demographic information about the participants was collected in the first section and items were aimed at assessing the online learning readiness of the participants in the second section. Hung et al. (2010) suggested that McVay's (2000) questionnaire did not concentrate on self-directed learning, motivation, and learner control. Hung et al. (2010) made some additions to their version of the OLRS to include these factors and other factors of computer and Internet self-efficacy and online communication self-efficacy. Therefore, the scale included five dimensions ( 18 items with a 5 point Lickert scale) as computer/Internet selfefficacy, self-directed learning, and motivation for learning, learner control, and online communication self-efficacy. Yurdugül and Alsancak Sirakaya (2013) developed the Turkish version of "Online Learning Readiness Scale" -OLRS- (Hung, Chou, Chen, \& Own, 2010) to investigate the psychometric properties. 


\section{Data collection procedures}

This study was conducted in order to gather information about the level of online readiness of students (1st, 2nd, and 3rd students) at Translation and Interpretation Department at Selçuk University. Before the application of the study, required permissions were obtained from the ethics committee of Selçuk University and permission for copyright was obtained from the owner the questionnaire used in the study. Also, students filled the Informed Consent form before the study.

An online scale belonging to the study of Yurdugül and Alsancak Sirakaya (2013) was administered to the students. 120 students from Translation and Interpretation Department at Selçuk University participated to the study (47 students from first grade, 31 students from second grade and 42 students from third grade). The questionnaire was applied via MOODLE (Modular-Object-Oriented-DynamicLearning-Environment) that was used as the tool of Distance Education System of Selçuk University.

\section{Data analysis}

The reliability coefficient of the scale was found to be Cronbach's Alpha coefficient $(\alpha=.864)$ in the study conducted for the Translation and Interpretation Department, and we can say that this value is a good level. As a result of the normality test performed according to the collected data, they were normally distributed according to the Kolmogorov-Smirnov value. Independent of parametric tests, ttest and one-way ANOVA test were used because they showed normal distribution. However, although our data set showed a normal distribution, the non-parametric tests Mann Whitney U and Kruskal Wallis $\mathrm{H}$ tests were performed because there was a numerical difference between the groups answering the questions "Access to computer and Internet" and "age group".

\section{Results}

Table 3. Online learning readiness levels of the students

\begin{tabular}{ll}
\hline Level & Mean \\
\hline Low & $18-41$ \\
Medium & $42-75$ \\
High & $76-90$ \\
\hline
\end{tabular}

The average value obtained over the total scores of the Online Learning Readiness scale applied to the students was found $(X=63.17)$. According to the table given above, it is seen that the level of "Online Learning Readiness" of this study group is Medium.

Table 4. One-way Anova Results to determine the relationship between the online learning readiness levels of the students and their class levels

\begin{tabular}{lllllll}
\hline Factors & Scores & $\begin{array}{l}\text { Mean } \\
\text { Square }\end{array}$ & sd & $\begin{array}{l}\text { Total Sum } \\
\text { Squares }\end{array}$ & F & p \\
\hline $\begin{array}{l}\text { Computer and } \\
\text { Internet Self- }\end{array}$ & Between-group & 10.92 & 2 & 5.46 & .79 & .45 \\
Efficacy & Within- group & 799.44 & 117 & 6.83 & & \\
& Sum & 810.36 & 119 & & 1.37 & .25 \\
\hline Self-Directed & Between-group & 34.31 & 2 & 17.15 & &
\end{tabular}

\begin{tabular}{r|l} 
Adres & Address \\
RumeliDE Dil ve Edebiyat Araşttrmaları Dergisi & RumeliDE Journal of Language and Literature Studies \\
Osmanağa Mahallesi, Mürver Çiçeği Sokak, No:14/8 & Osmanağa Mahallesi, Mürver Çiçeği Sokak, No:14/8 \\
Kadıköy - İSTANBUL / TÜRKIYY 34714 & Kadıköy - ISTANBUL / TURKEY 34714 \\
e-posta: editor@rumelide.com & e-mail: editor@rumelide.com, \\
tel: +90 505 7958124, +90 216773 o 616 & phone: +90 505 7958124, +90 216773 o 616
\end{tabular}




\begin{tabular}{|c|c|c|c|c|c|c|}
\hline & Sum & 1490.99 & 119 & & & \\
\hline \multirow[t]{3}{*}{ Learner Control } & Between-group & 3.79 & 2 & 1.89 & \multirow[t]{3}{*}{.35} & \multirow[t]{3}{*}{.69} \\
\hline & Within- group & 618.32 & 117 & 5.28 & & \\
\hline & Sum & 622.12 & 119 & & & \\
\hline \multirow{3}{*}{$\begin{array}{l}\text { Motivation for } \\
\text { Learning }\end{array}$} & Between-group & 2.22 & 2 & 1.11 & \multirow[t]{3}{*}{.13} & \multirow[t]{3}{*}{.87} \\
\hline & Within- group & 968.77 & 117 & 8.28 & & \\
\hline & Sum & 970.99 & 119 & & & \\
\hline \multirow{3}{*}{$\begin{array}{l}\text { Online } \\
\text { Communication } \\
\text { Self-Efficacy }\end{array}$} & Between-group & 6.47 & 2 & 3.24 & \multirow[t]{3}{*}{.41} & \multirow[t]{3}{*}{.66} \\
\hline & Within- group & 912.32 & 117 & 7.79 & & \\
\hline & Sum & 918.80 & 119 & & & \\
\hline \multirow[t]{3}{*}{ Total } & Between-group & 152.61 & 2 & 76.30 & \multirow[t]{3}{*}{.67} & \multirow[t]{3}{*}{.51} \\
\hline & Within- group & 13140.71 & 117 & 112.31 & & \\
\hline & Total & 13293.32 & 119 & & & \\
\hline
\end{tabular}

According to the findings in Table 4, there was no significant difference between the online learning readiness levels of the students $\left(\mathrm{F}_{2-117}=.79 ; \mathrm{p}>.05\right)$. When we compare the sub-factors of the online readiness scale with class levels, there was no significant difference between the sub-factors and class levels. (Computer and Internet Self-Efficacy $\left(\mathrm{F}_{2-117}=.79 ; \mathrm{p}>.05\right)$; Self-Directed Learning $\left(\mathrm{F}_{2-117}=1.37\right.$; $\mathrm{p}>$.05); Learner Control $\left(\mathrm{F}_{2-117}=35 ; \mathrm{p}>\right.$.05); Motivation for Learning $\left(\mathrm{F}_{2-117}=.13 ; \mathrm{p}>\right.$.05); Online Communication Self-Efficacy $\left(\mathrm{F}_{2-117}=.67: \mathrm{p}>.05\right)$. According to these results, it can be said that the online learning readiness and sub-factors of students studying in the department of translation and interpretation do not change according to the class levels. According to this, it shows that students at all class levels are familiar with the teaching in an online environment and do not have any difficulties.

Table 5. Independent t-test results to determine the online learning readiness levels of the students between their genders

\begin{tabular}{|c|c|c|c|c|c|c|}
\hline & Gender & $\mathbf{N}$ & $\mathbf{X}$ & SS & $\mathbf{t}$ & $\mathbf{p}$ \\
\hline \multirow{2}{*}{$\begin{array}{l}\text { Computer and } \\
\text { Internet Self-Efficacy }\end{array}$} & Male & 41 & 11.53 & 3.16 & \multirow[t]{2}{*}{1.27} & \multirow[t]{2}{*}{.20} \\
\hline & Female & 79 & 10.89 & 2.26 & & \\
\hline \multirow{2}{*}{$\begin{array}{l}\text { Self-Directed } \\
\text { Learning }\end{array}$} & Male & 41 & 16.24 & 3.98 & \multirow[t]{2}{*}{.77} & \multirow[t]{2}{*}{.4} \\
\hline & Female & 79 & 16.77 & 3.29 & & \\
\hline \multirow{2}{*}{ Learner Control } & Male & 41 & 9.53 & 2.51 & \multirow[t]{2}{*}{.30} & \multirow[t]{2}{*}{.76} \\
\hline & Female & 79 & 9.67 & 2.17 & & \\
\hline \multirow{2}{*}{$\begin{array}{l}\text { Motivation for } \\
\text { Learning }\end{array}$} & Male & 41 & 15.92 & 2.91 & \multirow[t]{2}{*}{.51} & \multirow[t]{2}{*}{.61} \\
\hline & Female & 79 & 15.64 & 2.84 & & \\
\hline \multirow{2}{*}{$\begin{array}{l}\text { Online } \\
\text { Communication Self- } \\
\text { Efficacy }\end{array}$} & Male & 41 & 10.97 & 3.00 & \multirow[t]{2}{*}{2.54} & \multirow[t]{2}{*}{.01} \\
\hline & Female & 79 & 9.64 & 2.55 & & \\
\hline \multirow[t]{2}{*}{ Total } & Male & 41 & 64.21 & 11.47 & \multirow[t]{2}{*}{.77} & \multirow[t]{2}{*}{.43} \\
\hline & Female & 79 & 62.63 & 10.10 & & \\
\hline
\end{tabular}

As seen in Table 5, there was no significant difference between the genders of the online learning readiness levels of the students $(t=.77 ; \mathrm{p}>.05)$. When we compared the sub-factors of the online 
readiness scale with gender, no significant difference was found between four sub-factors and gender (Computer and Internet Self Efficacy $(t=1.27 ; \mathrm{p}>.05)$; Self-Directed Learning $(t=.77 ; \mathrm{p}>.05)$. Learner Control $(\mathrm{t}=.30 ; \mathrm{p}>.05)$; Motivation for Learning $(\mathrm{t}=.51 ; \mathrm{p}>.05)$. A significant difference was found between genders and the Online Communication Self-Efficacy sub-factor $(t=2.54: p>.05)$.

It can be said that the online learning readiness level of students studying in the department of translation and interpretation does not change according to gender with Computer and Internet SelfEfficacy, Self-Directed Learning, Learner Control, Motivation for Learning. However, a significant difference was found between the Online Communication Self-Efficacy sub-factor of the online learning readiness scale and gender. When the averages were examined, it was found that male students had higher Online Communication Self-Efficacy levels than female students.

Table 6. Results of the Kruskal Wallis $\mathrm{H}$ test conducted to determine the relationship between online learning readiness levels of the students and their age groups

\begin{tabular}{|c|c|c|c|c|c|c|}
\hline Factors & Age Groups & $\mathbf{N}$ & Mean & sd & $\mathbf{X}^{2}$ & $\mathbf{p}$ \\
\hline \multirow{3}{*}{$\begin{array}{l}\text { Computer and } \\
\text { Internet Self-Efficacy }\end{array}$} & $18-20$ & 68 & 60.18 & & & \\
\hline & $21-23$ & 41 & 58.26 & 2 & 1.16 & .55 \\
\hline & 24 and above & 11 & 70.82 & & & \\
\hline \multirow{3}{*}{$\begin{array}{l}\text { Self-Directed } \\
\text { Learning }\end{array}$} & $18-20$ & 68 & 53.84 & & & \\
\hline & $21-23$ & 41 & 67.67 & 2 & 6.19 & .04 \\
\hline & 24 and above & 11 & 74.95 & & & \\
\hline \multirow[t]{3}{*}{ Learner Control } & $18-20$ & 68 & 54.65 & & & \\
\hline & $21-23$ & 41 & 66.43 & 2 & 5.00 & .08 \\
\hline & 24 and above & 11 & 74.55 & & & \\
\hline \multirow{3}{*}{$\begin{array}{l}\text { Motivation for } \\
\text { Learning }\end{array}$} & $18-20$ & 68 & 58.04 & & & \\
\hline & $21-23$ & 41 & 62.50 & 2 & 1.04 & .59 \\
\hline & 24 and above & 11 & 68.27 & & & \\
\hline \multirow{3}{*}{$\begin{array}{l}\text { Online } \\
\text { Communication Self- } \\
\text { Efficacy }\end{array}$} & $18-20$ & 68 & 58.23 & & & \\
\hline & $21-23$ & 41 & 61.09 & 2 & 1.60 & .44 \\
\hline & 24 and above & 11 & 72.36 & & & \\
\hline \multirow[t]{3}{*}{ Total } & $18-20$ & 68 & 55.83 & & & \\
\hline & $21-23$ & 41 & 63.77 & 2 & 4.12 & .12 \\
\hline & 24 and above & 11 & 77.18 & & & \\
\hline
\end{tabular}

According to the findings in Table 6, no significant difference was found between the readiness levels of online learning and age groups of students $\left(\mathrm{X}^{2}=4.12, \mathrm{p}>.05\right)$. When we compared the sub-factors of the online readiness scale with the age groups, no significant difference was found between four sub-factors and age groups (Computer and Internet Self Efficacy $\left(\mathrm{X}^{2}=1.16\right.$; $\mathrm{p}>$.05); Learner Control $\left(X^{2}=5.00 ; p>~ .05\right)$; Motivation for Learning $\left(X^{2}=1.04 ; p>~ .05\right)$; Online Communication Self-Efficacy $\left(\mathrm{X}^{2}=1.60 ; \mathrm{p}>.05\right)$. A significant difference was found between the age groups with the Self-Directed Learning $\left(\mathrm{X}^{2}=6.19 ; \mathrm{p}>.05\right)$.

Therefore, online learning readiness level of the students studying in the translation and interpretation department and the sub-factors Computer and Internet Self-Efficacy, Learner Control, Motivation for

\begin{tabular}{r|l} 
Adres & Address \\
RumeliDE Dil ve Edebiyat Araştırmaları Dergisi & RumeliDE Journal of Language and Literature Studies \\
Osmanağa Mahallesi, Mürver Çiçeği Sokak, No:14/8 & Osmanağa Mahallesi, Mürver Çiçeği Sokak, No:14/8 \\
Kadıköy - İSTANBUL / TÜRKIYE 34714 & Kadıköy - ISTANBUL / TURKEY 34714 \\
e-posta: editor@rumelide.com & e-mail: editor@rumelide.com, \\
tel: +90 505 7958124, +90 216773 0 616 & phone: +90 505 7958124, +90 2167730616
\end{tabular}


Learning, Online Communication Self-Efficacy and age groups do not vary. However, a significant difference was found between the Self-Directed Learning sub-factor of the online learning readiness scale and age groups. In order to determine the difference between the groups, according to the results of the double Mann Whitney U test, it can be said that those aged 24 and above were more successful in managing their own learning than those in the 18-20 age groups.

Table 7. The results of the Mann Whitney U test conducted to determine the relationship between the online learning readiness of the students and their access to computer and Internet

\begin{tabular}{|c|c|c|c|c|c|c|}
\hline & $\begin{array}{l}\text { Access to } \\
\text { computer } \\
\text { and Internet }\end{array}$ & $\mathbf{N}$ & Mean & Rank Sum & $\mathbf{U}$ & $\mathbf{p}$ \\
\hline \multirow{2}{*}{$\begin{array}{l}\text { Computerand } \\
\text { Internet Self-Efficacy }\end{array}$} & Yes & 106 & 63.06 & 6684.0 & 471.0 & .025 \\
\hline & No & 14 & 41.14 & 576.0 & & \\
\hline \multirow{2}{*}{$\begin{array}{l}\text { Self-Directed } \\
\text { Learning }\end{array}$} & Yes & 106 & 60.70 & 6434.5 & 720.5 & .860 \\
\hline & No & 14 & 58.96 & $825 \cdot 5$ & & \\
\hline \multirow{2}{*}{ Learner Control } & Yes & 106 & 60.29 & 6391.0 & 720.0 & .856 \\
\hline & No & 14 & 62.07 & 869.0 & & \\
\hline \multirow{2}{*}{$\begin{array}{l}\text { Motivation for } \\
\text { Learning }\end{array}$} & Yes & 106 & 60.64 & 6428.0 & 727.0 & .902 \\
\hline & No & 14 & 59.43 & 832.0 & & \\
\hline \multirow{2}{*}{$\begin{array}{l}\text { Online } \\
\text { Communication Self- } \\
\text { Efficacy }\end{array}$} & Yes & 106 & 63.40 & 6720.0 & 435.0 & .012 \\
\hline & No & 14 & 38.57 & 540.0 & & \\
\hline \multirow[t]{2}{*}{ Total } & Yes & 106 & 61.74 & 6544.5 & 610.5 & .282 \\
\hline & No & 14 & 51.11 & 715.5 & & \\
\hline
\end{tabular}

As can be seen in Table 7, when we compare the sub-factors of online readiness scale with their access to computer and Internet, a significant difference was found between Computer and Internet SelfEfficacy ( $U=471.0 ; p>.05)$ and Online Communication Self-Efficacy $(U=435.0 ; p>.05)$. However, no significant difference was found between Self-Directed Learning ( $U=720.0 ; p>.05)$; Learner Control ( $\mathrm{U}=720.0$; $\mathrm{p}>.05)$; Motivation for Learning $(\mathrm{U}=727.0$; $\mathrm{p}>.05)$ and their access to computer and Internet.

According to these results, it can be said that the level of online learning readiness of students studying in the department of translation and training and owning a computer with self-Directed Learning, Learning Control, Motivation for Learning can be said to have not changed. However, a significant difference was found between the Computer and Internet Self-Efficacy and Online Communication Self-Efficacy sub-factors of the online learning readiness scale and computer ownership. When the mean scores of sub factor levels are examined, it is seen that computer owners are higher than those who do not.

Table 8. Independent t-test results to determine the relationship between online learning readiness levels students and web-based education experience

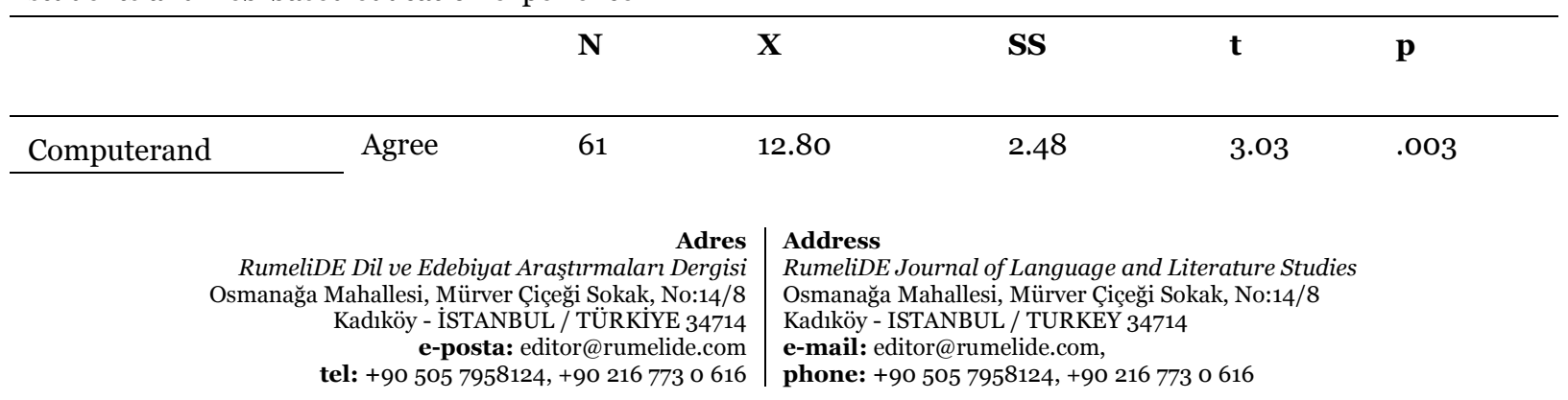




\begin{tabular}{|c|c|c|c|c|c|c|}
\hline InternetSelf-Efficacy & Disagree & 59 & 10.40 & 2.56 & & \\
\hline \multirow{2}{*}{$\begin{array}{l}\text { Self-Directed } \\
\text { Learning }\end{array}$} & Agree & 61 & 16.68 & 3.58 & \multirow[t]{2}{*}{.30} & \multirow[t]{2}{*}{.762} \\
\hline & Disagree & 59 & 16.49 & $3 \cdot 52$ & & \\
\hline \multirow{2}{*}{ Learner Control } & Agree & 61 & 9.93 & 2.21 & \multirow[t]{2}{*}{1.51} & \multirow[t]{2}{*}{.132} \\
\hline & Disagree & 59 & 9.30 & 2.33 & & \\
\hline \multirow{2}{*}{$\begin{array}{l}\text { Motivation for } \\
\text { Learning }\end{array}$} & Agree & 61 & 16.01 & 2.86 & \multirow[t]{2}{*}{1.07} & \multirow[t]{2}{*}{.286} \\
\hline & Disagree & 59 & 15.45 & 2.84 & & \\
\hline \multirow{2}{*}{$\begin{array}{l}\text { Online } \\
\text { Communication Self- } \\
\text { Efficacy }\end{array}$} & Agree & 61 & 10.52 & 2.85 & \multirow[t]{2}{*}{1.71} & \multirow[t]{2}{*}{.089} \\
\hline & Disagree & 59 & 9.66 & 2.64 & & \\
\hline \multirow[t]{2}{*}{ Total } & Agree & 61 & 65.96 & 10.90 & \multirow[t]{2}{*}{2.19} & \multirow[t]{2}{*}{.049} \\
\hline & Disagree & 59 & 61.32 & 10.19 & & \\
\hline
\end{tabular}

According to Table 8, a significant difference was found between the online learning readiness levels of translation and interpretation students and their participation in web-based education before $(t=2.19$; $\mathrm{p}<.05$ ). When we compare the results, no significant difference was found between four sub-factors of the scale and web-based education experiences of students (Self Directed learning ( $\mathrm{t}=.30 ; \mathrm{p}>.05$ ); Learner Control ( $\mathrm{t}=1.51 ; \mathrm{p}>$.05); Motivation for learning ( $\mathrm{t}=1.07 ; \mathrm{p}>$.05); Online Communication Self-Efficacy ( $t=1.71 ; p>$.05). On the other hand, a significant difference was found between the Computer and Internet Self-Efficacy sub-factor and web-based experience $(t=3.03 ; p<.05)$.

According to these results, it can be said that students studying in the department of translation and interpretation do not change according to their participation in web-based education with SelfDirected Learning, Learning Control, Motivation for Learning, Online Communication Self-Efficacy sub-factors of online learning readiness. When the averages were examined, it was found that those who participated in web-based education before were higher in both the total and Computer and Internet Self-Efficacy sub-factor compared to those who did not.

\section{Discussion}

Online readiness of students is important in the design and implementation of online learning. Therefore, evaluating students' readiness as well as their satisfaction with online courses is a necessary process for online learning applications to be successful. Every institution that will engage in distance education activity must focus on the readiness of students and instructors, even if their infrastructure is ready. Students who have never been exposed to online learning cannot be expected to adapt to this different learning environment immediately. There are different studies on readiness for online learning and different measurement tools used. This study uses the Online Learning Readiness scale developed by Hung, Chou, Chen, and Own (2010). Online learning readiness is discussed in terms of motivation, learner control, computer / internet self-efficacy, online communication self-efficacy and self-directed learning.

According to the results of the study the level of Online Learning Readiness of this study group is Medium. It shows that students at all class levels are familiar with the teaching in an online environment and do not have any difficulties. Also, a significant difference was found between the genders of the Online Communication Self-Efficacy sub-factor. When the averages were examined, it

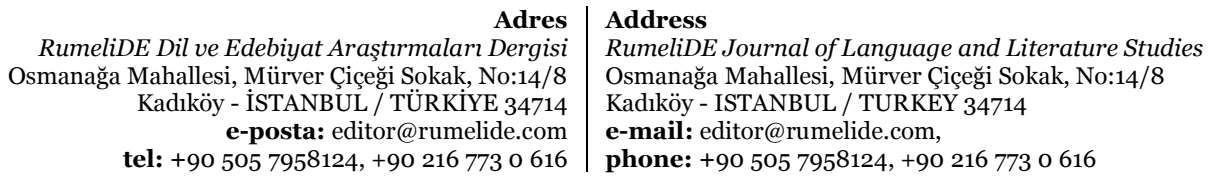


was found that male students had higher Online Communication Self-Efficacy levels than female students. In order to determine the difference between the groups, according to the results of the double Mann Whitney U test, it was determined that those aged 24 and above were more successful in managing their own learning than those in the 18-20 age groups. When we compare the sub-factors of online readiness scale with access to computer and Internet, a significant difference was found between Computer and Internet Self-Efficacy and access to computer and Internet. The sub-factors of the online readiness scale are compared with web-based education experience; it was found that those who participated in web-based education before were higher in both the total and the Computer and Internet Self-Efficacy compared to those who did not.

\section{Conclusion}

After the decision to suspend face-to-face education and lockdown across the country due to Covid 19, the higher education institution has decided to conduct classes online in order not to interrupt education in all universities. The fact that the online learning-teaching environments in the institutions are merely the necessary technology preparing the infrastructure and transferring the traditional face-to-face classroom environment to the electronic environment in the same way causes the provided online learning experience to be no more than a simple and bad imitation of traditional face-to-face learning. In this transition phase, in addition to the technological infrastructure, the quality of the course content and learning platforms, the attitude of the instructors and the new roles and competencies that the online learning environments assume for them, as well as the readiness of the students, who are the most important actors of online learning, are vital for the quality of the learning experience.

\section{Implications and suggestions}

Therefore, it is necessary to redesign our educational system and practices to provide effective online education. Digital computers, the Internet and Wi-Fi are not available to both teachers and students. There could be a lot of trouble with the lack of access to adequate digital infrastructure, no internet service, or Wi-Fi networks, which may lead to inequity in using digital learning opportunities.

Institutions should make efforts to ensure that both students and faculties have access to the appropriate services. They must also ensure that all educational applications also operate on cell phones, in the event that students do not have laptops. Measures must therefore be taken to will the digital divide. Students and instructors around universities have never really experienced e-learning. Most of them are complacent and are stuck with conventional teaching approaches.

An incentive to make the most of the current situation is the Covid 19 pandemic outbreak. We will learn a lot in this tough situation. Teachers are required to select the right tool and incorporate it with a lot of available tools to provide their students with education.

According to Dwahan (2020) "a step-by - step guide can be prepared by academic institutions that can guide teachers and students on how to access and use different e-learning resources and how to cover major curriculum content using these technologies, thus reducing digital illiteracy" (p. 16). The curriculum can be viewed in a variety of ways by teachers, i.e. photographs, audio, and texts can be used. If teachers augment their lectures with video calls, virtual meetings, and so on to get immediate input and establish a personal relationship with students, it is helpful.

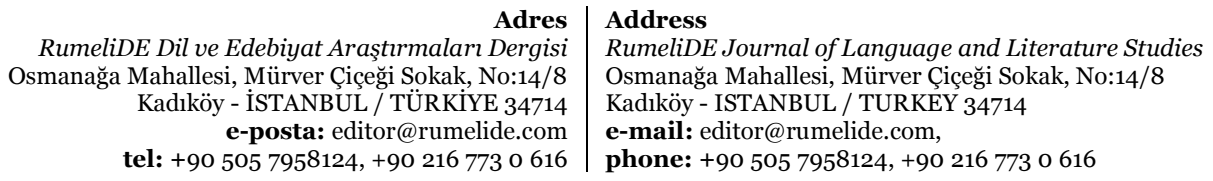


Everything takes time and before the outbreak of Covid 19 there was a resistance to Distance Education programs. Neither students nor academic staff were ready for emergency distance learning. We were not aware of the online learning platforms and applications in the Digital world surrounding us. Covid 19 immersed us in this digital world to maintain our education.

This study was carried out in the department of Translation and Interpretation to find answers to the research questions. It can be extended to other disciplines and can be replicated using with triangulation method.

\section{References}

Affouneh, S. \& Salha, S. \& Khlaif, Z. (2020). Designing Quality E-Learning Environments for Emergency Remote Teaching in Coronavirus Crisis. Interdisciplinary Journal of Virtual Learning in Medical Sciences. 11. 10.30476/ijvlms.2020.86120.1033.

Alshebab, M. (2013). The Impact of E-Learning in Students' Ability in Translation from English into Arabic at Irbid National University in Jordan. Journal of Education and Practice, 4(14), 123-133.

Bandura, A. (1977). Self-efficacy: Toward a unifying theory of behavioural change. Psychological Review, 84(2), 191-215.

Bozkurt, A. (2017). Türkiye'de Uzaktan Eğitimin Dünü, Bugünü ve Yarını. 3. 85-124.

Cojocariu, V. \& Iuliana, L. \& Nedeff, V. \& Lazar, G. (2013). SWOT Anlysis of E-learning Educational Services from the Perspective of their Beneficiaries. Procedia - Social and Behavioral Sciences. 116. 10.1016/j.sbspro.2014.01.510.

Colchester, K., Hagras, H., Alghazzawi, D.M., \& Aldabbagh, G. (2017). A Survey of Artificial Intelligence Techniques Employed for Adaptive Educational Systems within E-Learning Platforms. Journal of Artificial Intelligence and Soft Computing Research, 7, 47 - 64.

Çelen, F. K., Çelik, A., Seferoğlu, S. S. (2011). Yükseköğretimde Çevrimiçi Öğrenme: Sistemde Yaşanan Sorunlar ve Çözüm Önerileri. Journal of European Education, 1(1).

Dhawan S. (2020). Online Learning: A Panacea in the Time of COVID-19 Crisis. Journal of Educational Technology Systems. 2020;49(1):5-22. doi:10.1177/0047239520934018.

Dorri, R. \& Khani, F. (2018). Innovation in Translation Pedagogy Using Online Collaborative Translator Training, https://translationjournal.net/April-2018/innovation-in-translationpedagogy-using-online-collaborative-translator-training.html

Ellis R. \& Allen, M. (2004) Down with boring E-Learning - Interview with e-learningguru Michael Allen. Retrieved July 12th, 2009 from http://www.astd.org/LC/2004/0704_allen.htm.

Gilbert, N. \& Driscoll, M. (2002). Collaborative knowledge building: A case study. Educational Technology Research and Development. 50. 59-79. 10.1007/BFo2504961.

Granell, X. 2014. Multilingual Information Management: Information, Technology and Translators. UK: Chandos Publishing.

Guglielmino, P. \& Guglielmino, L. (2003). Are your learners ready for e-learning? In G. Piskurich (Ed.), The AMA handbook of e-learning. New York: American Management Association.

Hartnett, M. (2016). The Importance of Motivation in Online Learning. 10.1007/978-981-10-07002_2.

Hung, M., Chou, C., Chen, C. \& Own, Z. (2010). Learner readiness for online learning: Scale development and student perceptions. Computers \& Education, 55, 1080-1090.

Karsten, R., Roth, M. R. (1998). The relationship of computer experience and computer self-efficacy to performance in introductory computer literacycourse. Journal of Research on Technology Education, 31(1), 14-24.

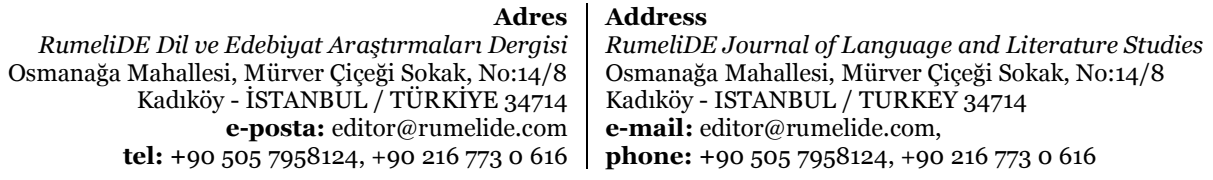

RumeliDE Dil ve Edebiyat Araştırmaları Dergisi e-posta: editor@rumelide.com tel: +90 505 7958124, +90 2167730616 
Kebritchi, Mansureh \& Lipschuetz, Angie \& Santiague, Lilia. (2017). Issues and Challenges for Teaching Successful Online Courses in Higher Education: A Literature Review. Journal of Educational Technology Systems. 46. 4-29. 10.1177/0047239516661713.

Knowles, M. (1975). Self-directed learning: A guide for learners and teachers. New York: Association Press.

Lawless, K. A., Brown, S. W. (1997). Multimedia Learning Environments: Issues of Learner Control and Navigation, Instructional Science, 25 (2), 117-131.

Lee, K., Tsai, P.S., Chai, C.S. \& Koh, J.H.L. (2014). Students' Perceptions of Self-Directed Learning and Collaborative Learning with and without Technology. Journal of Computer Assisted Learning, 30(5), 425-437. Retrieved January 19, 2021 from https://www.learntechlib.org/p/154012/

McVay, M. (2000). Developing a web-based distance student orientation to enhance student success in an online bachelor's degree completion program. Unpublished practicum report presented to the Ed.D. Program. Florida: Nova Southeastern University.

McVay, M. (2001). How to be a successful distance learning student: Learning on the Internet. New York: Prentice Hall.

Mnyanyi, Cosmas \& Mbwette, Tolly. (2009). Open and Distance Learning In Developing Countries: The Past, The Present And The Future.

Newby, T. J., Stepich, D. A., Lehman, J. D., \& Russell, J. D. (2000). InstructionTechnology for Teaching and Learning. Upper Saddle River, NJ: Merrill.

O'Donnell, E. (2010). The Student Perspective: Can the Use of Technologies Transform Learning? In R. Donnelly, J. Harvey, \& K. O’Rourke, Critical Design and Effective Tools for E-Learning in Higher Education (pp. 262-279). New York: IGI Global

Palloff, R. M., \& Pratt, K. (1999). Building Learning Communities in Cyberspace: Effective Strategies for the Online Classroom. San Francisco, CA: Jossey-Bass.

Pym, A. (n.d.). E-Learning and Translator Training. Retrieved March 9, 2018, from http://usuaris.tinet. cat/apym/on-line/training/2001_elearning.pd

Ryan, R. M., \& Deci, E. L. (2000). Intrinsic and extrinsic motivations: classic definitions and new directions. Contemporary Educational Psychology, 25(1), 54-67.

Schreurs, J., Sammour, G. \&Ehlers, U. (2008). E-learning Readiness Analysis (ERA): an e-health case study of e-learning Readiness. Int. J. Knowledge and Learning, 4(5), 496-508.

Shyu, H. Y., \& Brown, S. W. (1992). Learner control versus program control in interactive videodisc instruction: what are the effects in procedural learning? International Journal of Instructional Media, 19(2), 85-95.

Soni, Vishal Dineshkumar. (2020). Global Impact of E-learning during COVID 19. SSRN Electronic Journal. 12. 10.2139/ssrn.3630073.

Tang, S. F. \& Lim, C. L. (2013). Undergraduate students' readiness in e-learning: a study at the business school in a Malaysian private university. International Journal of Management \& Information Technology, 4 (2). 198-204.

Teo, Timothy \& Tan, Seng Chee \& Lee, Chwee Beng \& Chai, Ching \& Koh, Joyce \& Li, Chen \& Cheah, Horn. (2010). The self-directed learning with technology scale (SDLTS) for young students: An initial development and validation. Computers\&Education. 55. 1764-1771. 10.1016/j.compedu.2010.08.001.

Volery, T. \& Lord, D. (2000). Critical success factors in online education. The International Journal of Educational Management, 14(5). 216-223.

Wighting, M.J., Liu, J. \& Rovai, A.P. (2008). Distinguishing Sense of Community and Motivation Characteristics between Online and Traditional College Students. Quarterly Review of Distance $\begin{array}{lllll}\text { Education, } & 9(3), & \text { 285-295. Retrieved } & \text { May } & 28,\end{array}$ from https://www.learntechlib.org/p/106743/.

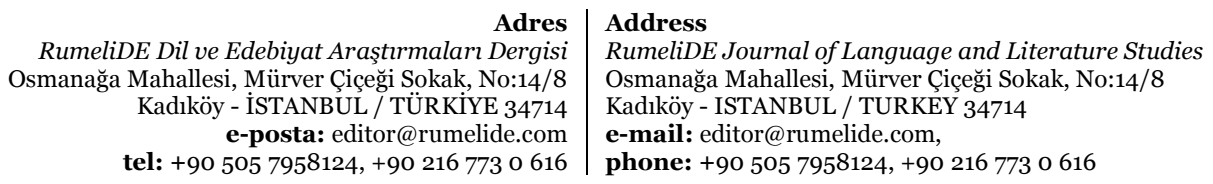


Yurdugül, Halil \& Alsancak Sirakaya, Didem. (2013). The Scale of Online Learning Readiness: A Study of Validity and Reliability. Egitim ve Bilim. 38. 391-406.

https://education.gov.gy/web/index.php/mediacenter/item/5663-ministry-of-education-covid-19health-advisory-as-at-march-23-2020 (Ministry of Education, 2020).

https://en.unesco.org/covid19/educationresponse (UNESCO, 2020a).

https://covid19.yok.gov.tr/Sayfalar/HaberDuyuru/opinion-turkish-higher-education-in-days-ofpandemic.aspx (YÖK, 2020f). 